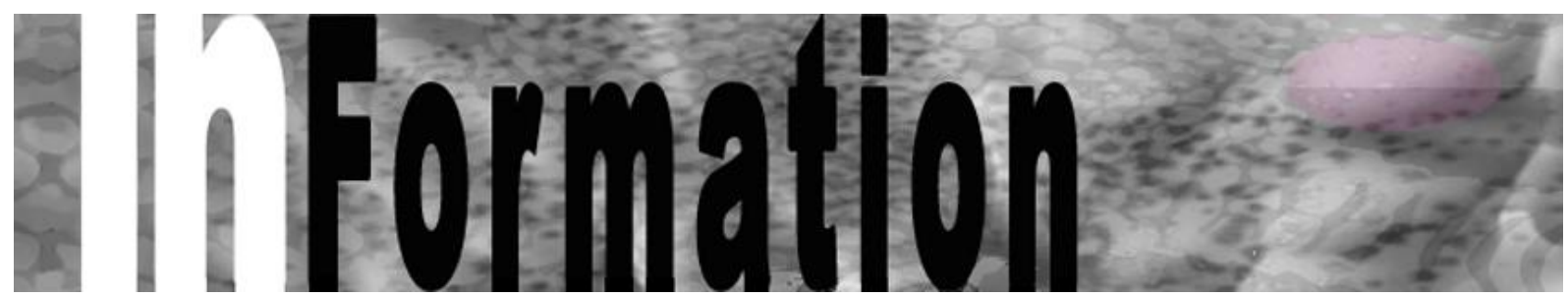

Nordic Journal of Art and Research

\title{
Mulighetsrommet i kunstdidaktikken: betraktninger av til-stede-værelse
}

\author{
Rikke Gürgens Gjærum¹ \\ Høgskolen i Oslo og Akershus
}

Sammendrag: Artikkelen utforsker kunstdidaktikken som et mulighetenes «rom» for marginale røster. Gjennom et stedsfilosofisk perspektiv blir begrepet «rom» det metaforiske omdreiningspunkt. Hensikten er å åpne opp for et undringsfelleskap der den filosofiske vandring fra rom til rom bidrar til å utvide vår forståelse av både marginalitet og kunstdidaktikk. Artikkelen bidrar dermed både med en begrepsutvikling og teoriforståelse av kunst for, av og med aktører med marginale røster, sett gjennom samtidskunsteksempler fra Disability Art-sjangeren representert ved DE UTVALGTE og UNLIMITED 2014.

Emneord: Marginalitet, filosofi, undring, funksjonshemming, kunstdidaktikk og rom.

\footnotetext{
${ }^{1} \mathrm{H} \varnothing g s k o l e n$ i Oslo og Akershus, Fakultet for teknologi, kunst og design, Institutt for estetiske fag. E-mail: rikke.gurgens@hioa.no
} 


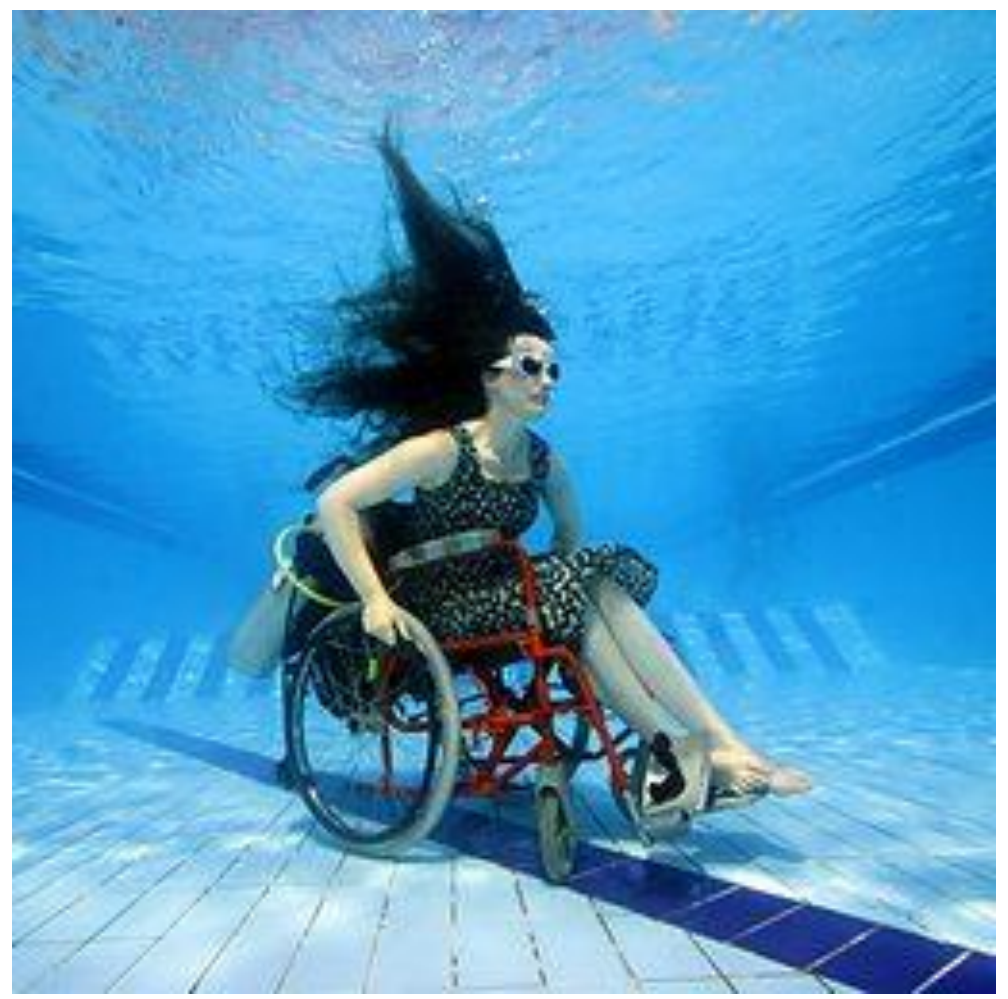

Sue Austin, Flying Free, Unlimted, 2014.

\section{Fra liv til forskning}

Jeg sitter, helt i ro på setet. Med en uro som kryper inn i meg. En visshet brer seg og befester en tiltagende gnagende uro. Jeg kommer meg ikke inn, jeg blir sittende og se, ser - men fatter fatte. De andre ler, ler høyt, titter på hverandre og ler anda høyere. Og her sitter jeg, utenfor latteren. Og jeg kan ikke en gang banke på, for jeg kommer ikke inn.

Opplevelsen av å være på utsiden sitter enda i meg. Som hørende forsker på tegnspråkteater blir det tradisjonelle bildet snudd. Det er den hørende som blir stående i en marginal sone, en sone som markerer linjen mellom innsiden og utsiden. Marginalisering innebærer en degradering av deg som menneske eller ekskludering fra en sosial sammenheng, «He is regarded as an outsider» (Becker, 1963, s.1). Det er med opplevelsen av selv å bli marginalisert at man blir satt i stand til å forstå hva det kan bety å bebo randsonen av samfunnet.

En marginal røst er en røst vi alle kan ha. Det er en kontekstuell røst som kan kjennes sterk, men knapt høres i offentligheten. Jeg er opptatt av å av-stigmatisere det marginale ved å bryte ned grensen mot marginale grupper, nettopp ved å trekke frem den allmennmenneskelige opplevelsen av «å føle seg utenfor». Det ufrivillige utenforskapet er gjenkjennelig i ethvert menneskeliv. Per Fugelli hevder at mennesket er en medfødt feilvare (Fugelli, 2013). Han betrakter alle mennesker som dypest sett likeverdige, uavhengig av diagnose, helse og funksjon, og minner oss om at vi alle har en skjevhet, en mangel, en rustflekk på sjelen eller en ripe i lakken. Vi kan alle være den som ikke passer inn, den som fremtrer som usedvanlig i felleskapets blikk. Ulike kontekstuelle settinger vil dermed produsere et mylder av marginale røster, av marginalitet og marginale grupperinger av forskjellige slag. 
Jeg vil i denne artikkelen utforske kunstdidaktikken som et mulighetenes rom for marginale røster og vil gjennom et stedsfilosofisk perspektiv benytte begrepet «rom» som metaforisk omdreiningspunkt. Hensikten er å åpne opp et undringsfelleskap der den filosofiske vandring fra rom til rom bidrar til å utvide vår forståelse av både marginalitet og kunstdidaktikk. I den filosofiske vandringen er subjektet og objektet uløselig knyttet til hverandre som i en uatskillelig relasjon.

Grunntonen i artikkelen er av fenomenologisk karakter, siden kunstdidaktikkens møte med marginale røster går gjennom det Merleau-Ponty (2004) omtaler som den kroppslige tilgang til stedet. Kunstdidaktikken byr på til-stede-værelse og knytter dermed eksistensen sammen med omgivelsene når marginale røster settes i spill. Av den grunn har jeg i utvalget av kunsteksempler vært på jakt etter interessante disability art-representanter der nettopp stedet og kunstarten blir satt i spill med den spesifikke funksjonsnedsettelsen på en slik måte at kunsten makter å kommunisere en form for sanselig erkjennelse hos betrakteren. Jeg valgte et anvendt drama- helseprosjekt, et samtidsteaterprosjekt, en foto- og lydinstallasjon, en koreografert undervannsdans og en film av sovende kropper. Disse prosjektene dekker et vidt spekter av kunstarter, mulige diagnostiske betegnelser og marginalitetsforståelser. Det metodologiske arbeidet med å utvikle en ramme for undringsfellesskapet og den filosofiske vandringen er videre basert på hermeneutisk fenomenologi fra Max Van Manen (1990). For ham handler fenomenologien om å trenge bakenfor, inn og innenfor de undersøkte fenomenene. Van Manen mener at hermeneutisk-fenomenologisk forskning handler om å utforske den levde erfaringen slik den oppleves intuitivt. Dette er en metodisk plattform som er oppdagelsesorientert og dermed både rettet mot å beskrive og tolke data som inngang til å forstå levd liv (Clancy \& Svensson (2007)). Analysen av kunsteksemplene har bestått av en dialog mellom filosofi og verk, tolket gjennom meg som forsker, med blikket rettet mot å avdekke kunstdidaktiske grep som åpner muligheter for de marginale røster til å ytre seg.

\section{Rom}

Før vandringen kan ta til, ønsker jeg å definere begrepet rom. Rom kan bety en struktur separert med skiller eller en oppdeling. Rom brukes også om de som er til stede (hele rommet lo), eller for å omtale muligheter (rom for forbedring). Vi kjenner til hvordan begrepet kan benyttes for å omtale begrensing (det var ikke rom for mer), eller brukes når vi snakker om kapasitet (han hadde ikke rom for politikk). ${ }^{2}$ Rom kan være så mangt. I denne artikkelen vil vi bevege oss igjennom fire rom, det objektivt gitte rommet, aktivitetsrommet, det fornemmede rommet og rommeligheten (Pahuus, 2015). Disse fire rommene strukturerer artikkelen og gir oss rom til undringsfellesskapet der vi skal utforske marginalitet og kunstdidaktikk. De fire rommene er valgt fordi de dramaturgisk sett bidrar til å analysere den performative kunstens grunnelementer som sted, tid, fabel/fortelling og karakter, men også fordi de rommer kunstens kommunikative premiss der verk, betrakter og skaper står i en dialogisk treenighet. De fire rommene gir oss som analytikere et grep å feste blikket med, når vi skal analysere kunstverk i lys av et mulig kunstdidaktisk potensiale.

Både filosofien og estetikken bidrar med ulike måter å forstå slike tankerom på. Rommene er tankekonstruksjoner som gir oss muligheten til å betrakte verden fra et metaperspektiv. Filosofen Kari Martinsen er opptatt av hvordan. "/.../ et fiktivt rum dannes, hvor vi får bevægelsesrum til at bruge fantasien" (Martinsen, 2012, s. 41). Dette bevegelsesrommet åpner opp for estetikkens språk og klokskapsdimensjonen som Martinsen hevder bidrar til «Det vitenskapelige rom [som] er et

\footnotetext{
${ }^{2}$ http://dictionary.reference.com/browse/room
} 
forståelsesrom, hvor forståelsen forholder seg til sanseinntrykket som noe sigende» (Martinsen, 2015, s.19). Men hvor finner vi disse «rommene», i verden eller i oss selv? Den danske filosofen Knud Ejlert Løgstrup (1978) viser oss at det er gjennom tilliten, medlidenheten og oppriktigheten at vi finner «rom».

De gir tanker og følelser rom, og settes i bevegelse av dem. De fører oss ut i livet med medmennesker og natur /.../ Løgstrup skriver at disse fenomenene suverent bærer vårt liv. De er gitt ved livet selv, og Løgstrup kaller dem suverene livsytringer (Martinsen, 2015, s.21).

Det altså disse livsytringene vi skal forfølge gjennom artikkelens fire rom for å forsøke å forstå hvordan kunstdidaktikken kan bli et mulighetenes rom for marginale røster der tillitten, medlidenheten og oppriktigheten gis gode vekstvilkår som suverene livsytringer. Vi vender oss først til det objektivt gitte rommet.

\section{Det objektivt gitte rommet}

Man kan nærme seg det objektivt gitte rommet i kunstdidaktikken dersom vi betrakter didaktikken som phronesis. Phronesis er ifølge Aristoteles (1999) menneskets praktiske visdom eller kløkt som gir det mulighet til å gjøre det som er godt og gagnlig for menneskene. Phronesis:

/.../ er det skøn, som bringes i spill, når man står i en situasjon, hvor man er klar over at de valg man træffer, de handlinger man foretager, lige så godt kunne være andre valg/.../

(Hansen, 2008, s. 278).

Skjønnet er knyttet til menneskets intuitive fornemmelse, kulturelle normer, verdier og tause kunnskap. Når kunstdidaktikken settes i spill som en Aristotelisk phronesis-dimensjon, blir den forstått som sanselig, relasjonell og intuitiv. Den er kulturelt og kontekstuelt betinget. Kunstdidaktikken muliggjør dermed flere former for objektivt gitte rom. Vi kan tenke oss kunstdidaktikken bragt inn i sykehuslovenes sanselig-empatiske univers. Da skaper kunstdidaktikken møter i sykehuskroppen forstått som sykehusets arkitektoniske bygningsmasse, men også pasientens kropp, en kropp som rommer en marginal røst og som er under behandling. Kunstdidaktikken blir dermed møtepunktet mellom det syke og det friske i mennesket:

Everyone who is born hold dual citizenship, in the kingdom of the well and in the kingdom of the sick (Sontag, 1991, s.3)

Alle mennesker kan bli syke. Det er imidlertid viktig å påpeke at også den syke har en frisk halvdel som trenger næring og trøst for å gi livsmot til å helbrede den syke siden. Syke-huset har en iboende dramatikk i den stedsspesifikke dramaturgi og scenografi (Brodzinski, 2010). Helseinstitusjonen er altså ikke «the empty space» (Brook, 1995, s.11). Den er et landskap fylt med sosial mening; med frykt, makt, forventing og håp (Foucault, 1972, s.166). Menneskelig varme og dialog utvider den sceniske rammen når sykehusklovnen viser oss hva teater kan være, slik bildet under viser: 


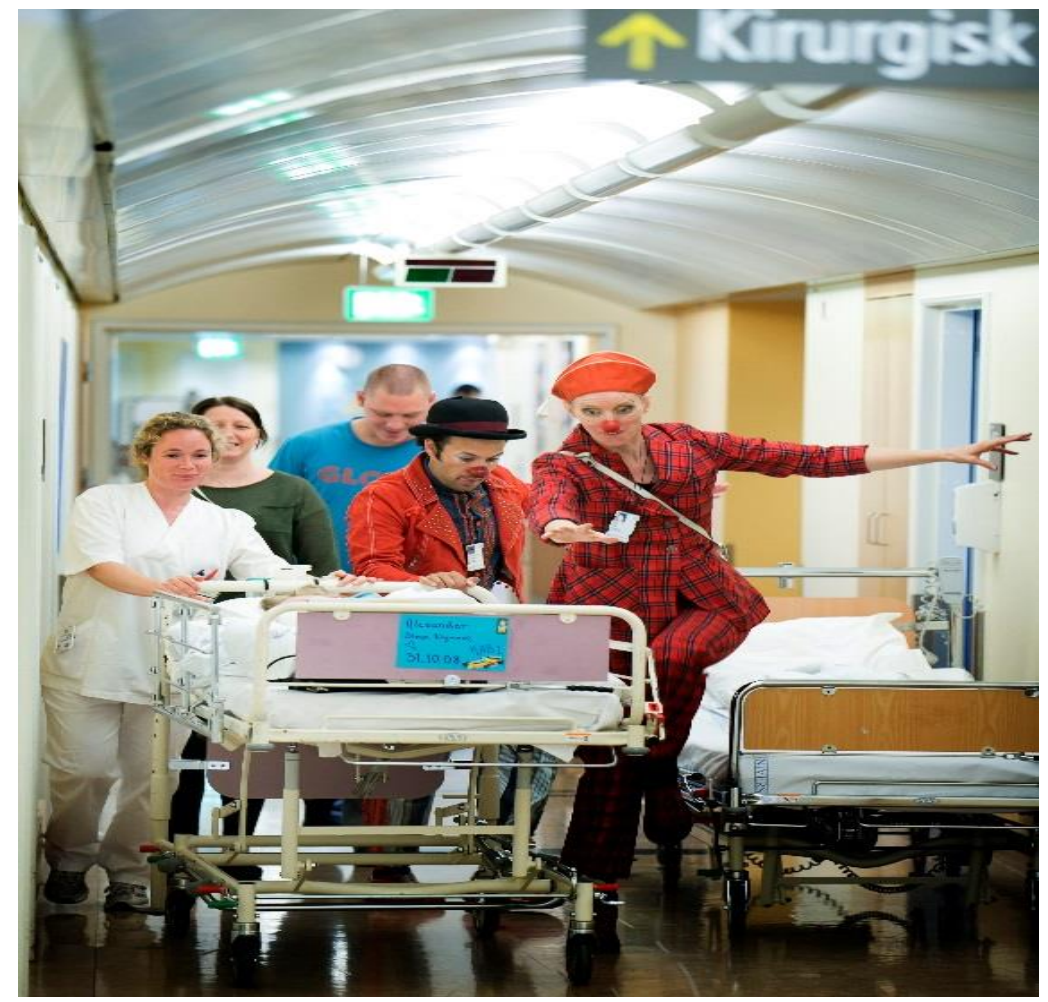

Når Alexander Steen Nymoen (5) våkner fra narkose har han fått et kort med hilsen fra sykehusklovnene. (FOTO: Heiko Junge / NTB scanpix)3

Hospital-begrepet kommer fra latin og betyr hospitality eller gjestfrihet. Vi ser at kunstdidaktikken innenfor sykehuset setter tillitten, medlidenheten og oppriktigheten i spill gjennom den estetiske prosessen når klovnen er gjest ${ }^{4} \mathrm{i}$ det medisinske univers (Brodzinski, 2010). Gjesten frir til pasienten, inviterer ham med i spillet og åpner med en kunstdidaktisk inngang et mulighetsrom i fiksjonen og leken. Sykehusklovnens fagkunnskap gir pasienten muligheten til å erfare liv for å fatte mot i sykehusets korridorer eller behandlingsrom, rom man kan definere som «objektivt gitte rom». Vi kan også tenke oss kunstdidaktikken bragt inn i ulike institusjoner eller steder, som i museet, i fengselet, i skolen, i biblioteket eller i asylmottaket. Da vil helt andre objektivt gitte rom åpne seg enn det sykehuseksemplet byr på. Men vi velger nå å gå videre og vender oss til aktivitetsrommet for å betrakte hva dette kan romme for marginale røster.

\section{Aktivitetsrommet}

Kunstdidaktikken anvendes både av formidlere av kunst og av produsenter av kunst der de fasiliterer en formidlingssituasjon forstått som et didaktisk møte mellom verket (produktet), betrakter (som medskapende aktør) og seg selv som formidler (medskaper). I formidlingssituasjonen trer man inn i «aktivitetsrommet». Dette rommet understreker det faktum at alle som inngår i den kunstdidaktiske konteksten, alltid er aktører eller medskapere av hendelsene som oppstår i møtet mellom dem. Hendelser man kan erfare som estetiske erfaringer (Dewey, 1934). Slikt sett forstår vi her kunstdidaktikken som en form for relasjonell estetikk (Bourriaud, 2007). Aktivitetsrommet er nært knyttet til livet selv:

\footnotetext{
${ }^{3}$ http://www.abcnyheter.no/livet/2013/08/24/180480/varsomme-sykehusklovner-muntrer-opp-desyke?nomobile=1

${ }^{4}$ «jest»-begrepet er hentet fra Phillip Taylors (2003) definisjon av anvendt teater, der teaterfasilitatoren er en gjest som reiser ut for å anvende teateret i samfunnet: «/.../outside of conventional mainstream theatre houses» (Taylor, 2003, p. 3).
} 
«Det mest grundlæggende form for aktivitetsrummet er livsopholdenes rum - et rum som kan antage de forskelligartede udformninger / . . / bestemt av den menneskelige krop og af de menneskelige behov» (Pahuus, 2015, s.123). La oss nå se på noen forskjellige aktivitetsrom som nettopp oppstår som resultat av aktørens kropp og behov for å utrykke seg og for å være-i-verden.

Teatergruppen DE UTVALGTE markerer i 2015 sitt 21 -års jubileum på Black Box i Oslo og viser i den forbindelse syv forestillinger skapt av regissør Kari Holtan, videodesigner Boya Bøckman, skuespiller og tekstutvikler Torbjørn Davidsen og dramaturg Anne Holtan. Ensemblet har gitt publikum «/.../forestillinger med et egenartet og mangefasettert formspråk, hvor stort sett alle bestanddelene er skapt av de involverte i forestillingene». ${ }^{5}$ En av disse forestillingene, som også er kalt «De utvalgte», er interessant sett i lys av det aktivitetsrommet man åpner opp for i møtet mellom kunstdidaktikken og marginale røster. Friteatergruppen arbeider i sceneproduksjonen med en gruppe mennesker de opplever $\ll / \ldots /$ marginaliseres og faller utenfor normalitetsbegrepet». ${ }^{6}$ Friteatergruppen hevder at:

Mennesker kategoriserer hverandre ved å se etter tegn på om man er i samme kultur eller i samme inngruppe, på grunnlag av ulikhet eller nærhet til inngruppen. Vi måles opp mot normer for atferd, gjennomsnitt for intellektuelle evner og kulturelt aksepterte emosjonelle uttrykk. Skal man tro evolusjonspsykologene har vi en nedarvet skepsis mot det vi opplever som annerledes og fremmedartet. ${ }^{7}$

Det interessante i produksjonen er måten samfunnet kritiseres politisk på av autentiske marginale røster fra scenen. Skuespillerne viser «evnen til å ta verden til seg, føle samklang med universet og gjenkjenne seg selv i den andre», ifølge teaterkritikeren Therese Bjørneboe (2012). Gjennom en visuell og digital rammesatt kunstdidaktikk kommuniserer ensemblet direkte med publikum, siden de makter å skape en visuell reise for oss som sitter med 3D-briller i salen og titter inn i et stort univers med stjernekikkert:

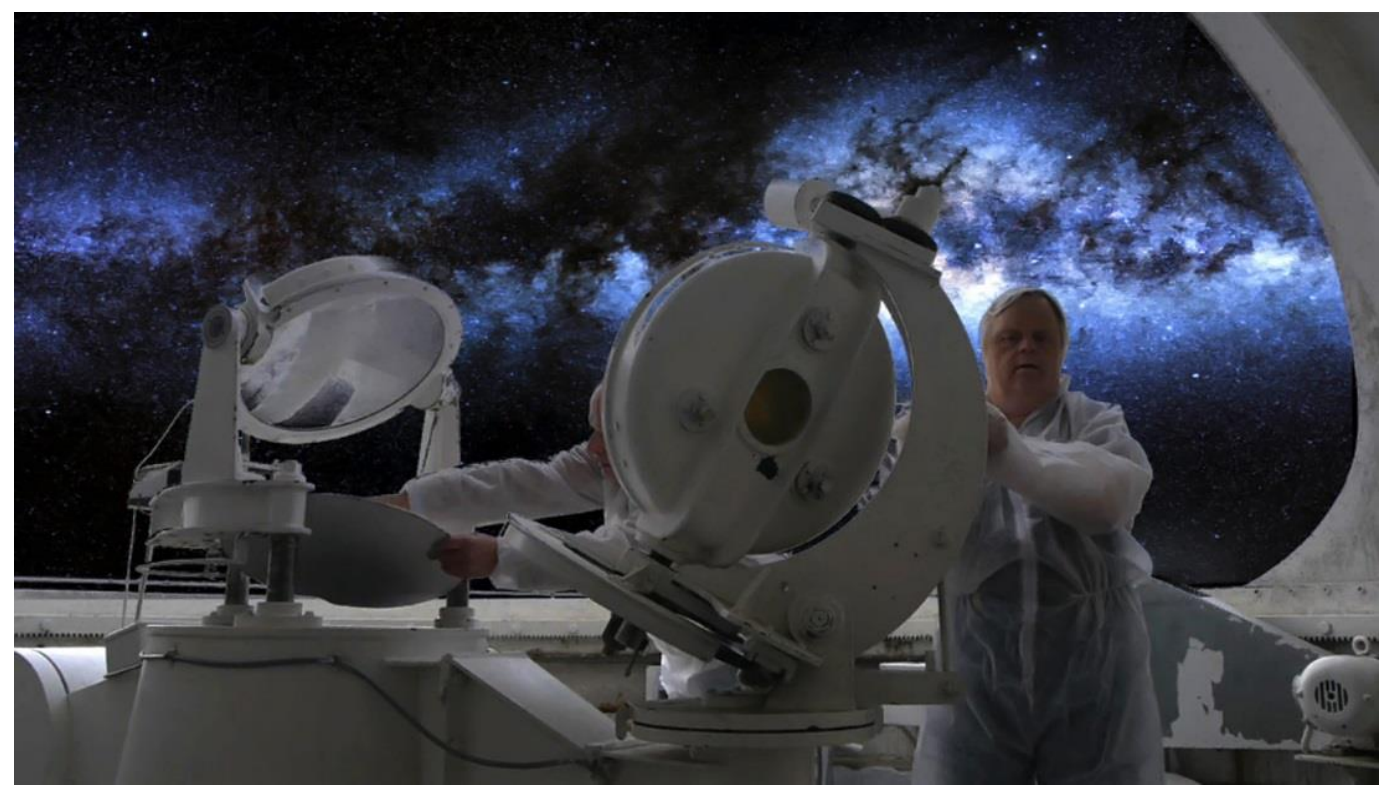

De utvalgte er et stykke «Disability Art» (Conroy, 2009) som evner å kritisk iscenesette menneskets trang til å kategorisere noe som «vanlig» og alt annet som «usedvanlig» (Gürgens, 2004). Disability Art er ikke bare en kunstenklave som gir mennesker med funksjonsnedsettelser et sted å utforske kunsten, det er også en måte å betrakte menneskeheten og samfunnet på (Conroy, 2009). Teaterforestillingen

\footnotetext{
${ }^{5}$ http://www.deutvalgte.no/portfolio_page/de-utvalgte/ ${ }^{6} \mathrm{http}: / / \mathrm{www} . d e u t v a l g t e . n o / p o r t f o l i o \_p a g e / d e-u t v a l g t e /$ ${ }^{7} \mathrm{http}$ ///www.deutvalgte.no/portfolio_page/de-utvalgte/
} 
«/.../ åpner et stort assosiasjonsrom/.../ [som] handler om hvordan vi ser hverandre» (Hammer, 2012). ${ }^{8}$ I salen blir vi trukket ut av fiksjonen og inn i eget liv, siden aktørene oppfordrer oss til å oppriktig tenke igjennom egne fordommer og egen trang til å dømme. Vi trer inn i aktivitetsrommet sammen med skuespillerne og musikerne. «Det at være aktiv er at være på vej mod noget (foran en). Menneske har altså i en vis forstand altid en vandring (livsvejen)" (Pahuus, 2015, s.123). Publikum tar fatt på egen livsvei med teateret som fartøy. Kunstdidaktikkens relasjonelle vesen trer tydelig frem for oss idet vi med oppriktighet retter blikket ut av salen, inn i livet og mot egen væren-i-verden (Heidegger, 1962). Aktivitetsrommet konstitueres således av kunstdidaktikkens performative vending. ${ }^{9}$ Den danske filosofen Mogens Pahuus påpeker at:

rumlighed er kendetegnet ved Ausrichtung (dette at vi altid er rettet mod - har et bestemt perspektiv på) og Entfernung (dette at vi gjør det værende nær-værende). Dermed får tingene rumlighed, som består i, at de er vedhåndværende (Zuhandkeit) i en brugs-kontekst, hvor nærhed og fjernhed (afstand) har mindre med geometrisk forstand end med at tilgængelighed ad gøre, og hvor det centrale rumsbegreb er den plads tingen har (Pahuus, 2015, s.123).

Det er med teaterets anvendelse av kunstdidaktiske relasjonelle grep at tilgjengeligheten stilles til skue. Publikum får tilgjengelighet til egne livserfaringer via sceniske assosiasjoner og tilgjengelighet til å grunne over egen væren-i-verden. Teateret anvendes i en bruks-kontekst som fremtrer som et potent aktivitetsrom der vi som er til stede blir nærværende. Vi nærmest reiser oss og «rekker opp hånden for deg!». ${ }^{10}$ Vi engasjeres og tar medfølende parti for de som vanligvis ikke høres i offentligheten, men som DE UTVALGTE bringer inn i scenerommet. Volumet på røstene settes dermed opp, og plutselig hører vi på det døve øret.

Men temaet utvelgelse blir også presentert på en måte som er like enkel som genial, idet ensemblet iscenesetter den bibelske fortellingen om Noahs ark. Gud ba Noah om å velge ut syv par av alle de «rene», og to par av de «urene» dyreartene. (Bjørneboe, 2012). ${ }^{11}$

Gjennom forestillingen kan man fornemme hvordan ensemblet «/...pløyer ukjent mark gjennom å bruke mennesker med nedsatt funksjonsevne som aktører i en forestilling som tematiserer kulturell og naturlig utvelgelse». ${ }^{12}$

\footnotetext{
${ }^{8} \mathrm{http}: / /$ www.scenekunst.no/pub/scenekunst/main/?aid=1919

${ }^{9}$ Aure, 2013.

${ }^{10}$ Uttrykket er hentet fra boken: Jeg rekker opp hånden for deg: Når storebror har Downs syndrom, av Trønnes-Christensen (2014).

${ }^{11}$ http://www.osloby.no/oslopuls/kunst_og_scene/En-forestilling-som-er-sa-vakker-at-det-gjor-vondt7051235.html

${ }^{12}$ http://www.deutvalgte.no/portfolio_page/de-utvalgte/
} 


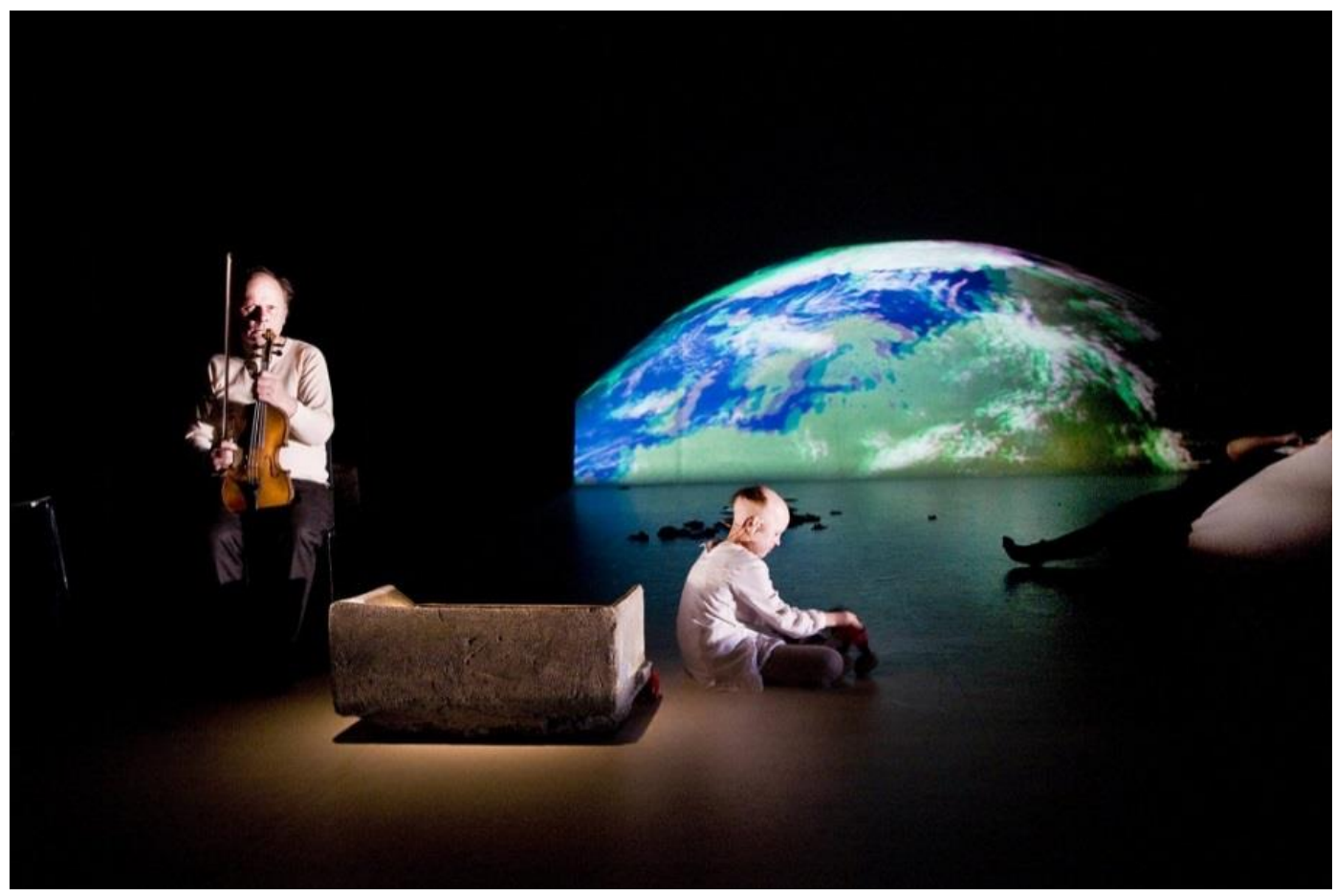

Forestillingen begynner idet skuespilleren Lotte Tvedt, ${ }^{13}$ som vi ser sittende på bildet, resiterer med lav og monoton røst:

\author{
Aprikostrærne finnes. \\ Bregnene finnes. \\ Dagene finnes. \\ Døden finnes. \\ Ensomheten finnes. \\ Einerbærbusken finnes. \\ Eddiken finnes. \\ Grågåsa finnes. \\ Grågåsas unger finnes. \\ Det tilfeldige, \\ Det systematiske finnes. ${ }^{14}$
}

Diktet Alfabet brukes både innledningsvis og avslutningsvis i forestillingen, og ordene undersøkes på de medvirkendes premisser, ifølge ensemblet. ${ }^{15}$ Nettopp autensiteten og sårbarheten som settes til skue minner oss om at $\ll / .$. /det fiktive rum er således ikke [kun] et opdigtet eller inbildt rum, men skapende, stemt af indtryk» (Martinsen, 2012, s. 42). Diktets plass i aktivitetsrommet gir oss fornemmelsen av nettopp det stemte inntrykk:
Jorden i sin bane om solen finnes
Jorden på sin rute gjennom melkeveien finnes
Med vannmasser, landmasser
Jordskjelv finnes
Du tenker på ord som kromosomer
Og på kjærlighetsfruktenes feilslåtte vekst
Et sted blir jeg plutselig født ${ }^{16}$

\footnotetext{
${ }^{13}$ Skuespilleren har Downs Syndrom.

${ }^{14}$ Hentet fra Inger Christensens diktsamling Alfabet.

${ }^{15} \mathrm{http}: / / \mathrm{www}$.deutvalgte.no/portfolio_page/de-utvalgte/

${ }^{16} \mathrm{http} / / / \mathrm{www}$. deutvalgte.no/portfolio_page/de-utvalgte/
} 
Vi har vandret gjennom et aktivitetsrom, scenerommet, der kunstdidaktikken inngår emansipatorisk i møte med marginale røster (Freire, 1996). Man kan tenke seg flere andre aktivitetsrom med en kunstdidaktisk ramme, f.eks. atelieret, verkstedet, museet, klasserommet eller kirkerommet der tilliten, medlidenheten og oppriktigheten på en annen måte settes i spill. Vi vender nå blikket mot det fornemmede eller opplevde rommet og skal se på hvordan Disability Art ytterligere kan manifestere seg og by på opplevelser.

\section{Det fornemmede rommet}

$\AA$ fornemme betyr å ane, kjenne, sanse og erfare. Fornemmelse handler om en sanselig erkjennelse (Gadamer, 2012). Utrykket «å fornemme» brukes imidlertid ofte når vi omtaler opplevelser vi ikke helt kan sette ord på eller peke på som klare, tydelige tegn. Vi fornemmer når vi kjenner at noe skjer, som om kroppen tar verden inn i seg og lar fornemmelsen modne inntil vi har analysert opplevelsen, plassert den og blitt i stand til nettopp å sette ord på den.

Aktivitetsrommet er stedet der man er et aktivt vesen som tar del i samspill med andre i felles utforskning, ofte med et $\emptyset$ nske om å komme videre i en målrettet handling som gir mestring. Da er kroppens behov og menneskets muligheter eneste begrensing i et livsoppholdenes rom der vi er på vei, rettet mot noe (Pahuus, 2015) Det fornemmede rom er derimot det stedet der man stilltiende kan være inne i seg selv og der det opplevde er subjektivt, kroppslig og emosjonelt. Man er ikke avhengig av andre i prosesseringen av opplevelsen i ens indre. Det fornemmede rommet er ifølge Pahuus (2015) nært knyttet til «dansen» eller «vandreturen» i skog og mark. Der er ikke distansen selve målet, man kan bevege seg på kryss og tvers, man kan danse baklengs og i sirkler, det essensielle blir $\ll / . . . /$ dimensjoner som vidde og dybde - og en skiften mellom det åpne versus det lukkede» (Pahuus, 2015, s.127).

Det er interessant å se på kunstfestivalen UNLIMITED i London for nettopp å betrakte fornemmede rom. Southbank Centre huser annenhvert år en tverrkunstnerisk festival med profesjonelle kunstnere som har en funksjonsnedsettelse: «The UNLIMITED commissions celebrate the work of disabled artists on an unprecedented scale. ${ }^{17}$ Festivalen $\varnothing$ nsker å utfordre kunstbegrepet, utvide betrakterens horisonter og provosere offentligheten gjennom modige og særegne «on the edge»- kunstprosjekter fra velrennomerte og etablerte Disability Art-kunstnere. ${ }^{18}$ UNLIMITED $\varnothing$ nsker å delta i en kulturpolitisk prosess. Kontekstuelt er det viktig å påpeke at Storbritannia har lange tradisjoner med sterke SelfAdvocate-grupper og politisk fundert Disability Studies-forskning.

Storbritannia er et foregangsland når det gjelder å løfte frem funksjonshemmedes (marginale) røster ${ }^{19}$ og gi dem plass, respekt og lytterverdige sceniske, auditive og visuelle forhold. UNLIMITED er en festival som fasliterer freelance kunstnere og gir dem muligheten til å innta Southbank Centre og møte sitt publikum. De legger forholdene til rette for at kunstinteresserte kan oppleve Disability Art på kunstens premisser (Gürgens, 2004). Vi skal nå se på to eksempler fra festivalen som på ulik måte treffer sitt publikum og skaper fornemmelser i dem.

\footnotetext{
${ }^{17}$ http://UNLIMITED.southbankcentre.co.uk/

${ }^{18} \mathrm{http}: / / \mathrm{www}$.disabilityartsonline.org

${ }^{19} \mathrm{http}: / / \mathrm{www}$. roaring-girl.com/work/resistance/
} 


\section{Stedsspesifikke prosjekter}

Det første prosjektet vi skal se nærmere på, er The Doorways Project som er en site-specific lydinstallasjon der kunstneren Bekki Perriman (2015) utforsker hjemløses historier om hjemløshet med lyd og bilder. ${ }^{20}$ Perriman $\varnothing$ nsker:

/ .../to offer homeless people a voice in the mainstream culture will offer a range of audience an opportunity to engage with the issues which, on the whole, remain, or are kept-invisible (Perriman, 2015).

Det å leve på siden av normaliteten, enten man er hjemløs eller har en funksjonsnedsettelse er knyttet til synlighet, usynlighet og hypersynlighet, Ifølge den funksjonshemmede samtidskunstforskeren Petra Kuppers:

Living with a visible disability can be experienced as a radical form of everyday performance, which exists in between the phenomenon of «hyper-visible» and «invisible» in everyday life (Kuppers, 2006, s. 26).
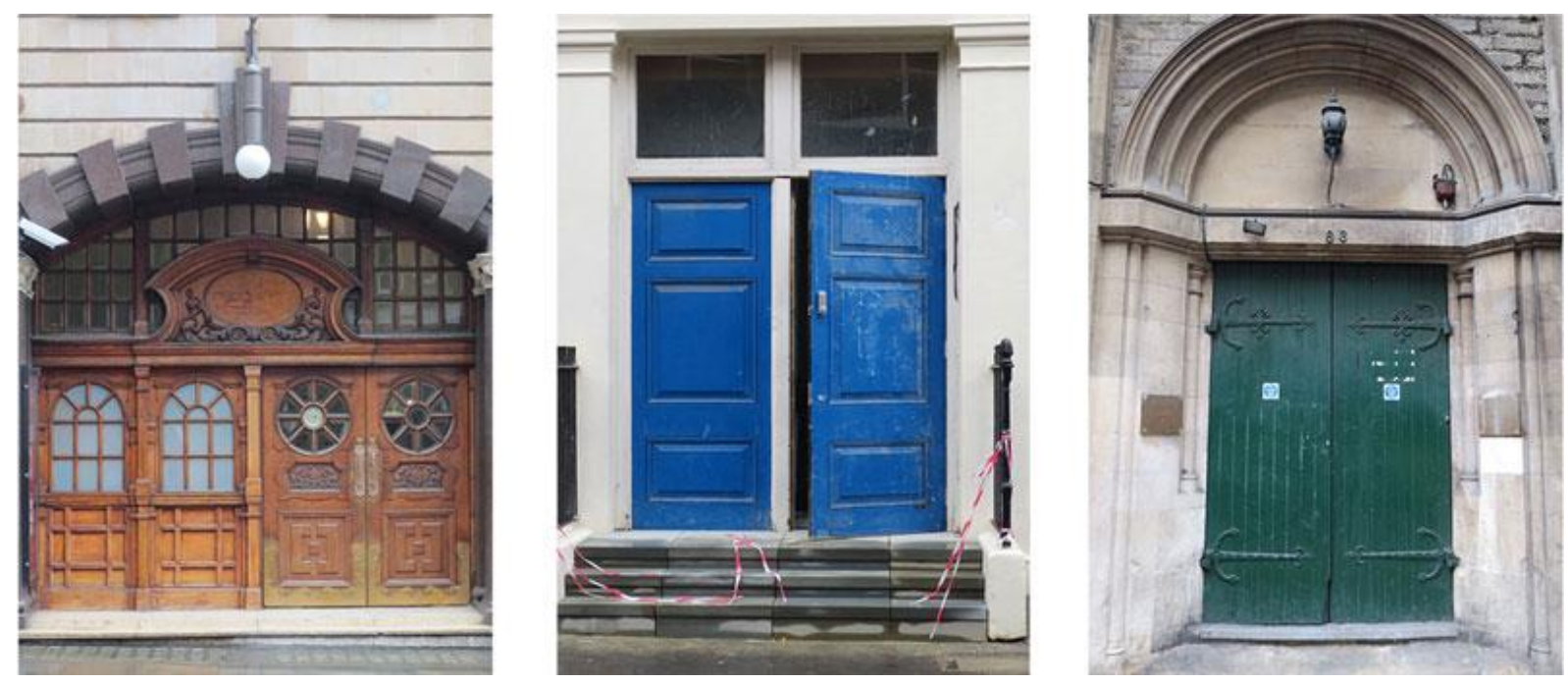

Kunstneren har selv erfaringer med å bli gjort usynlig, av å fornemme gaten som en «inside-homeless position». Han har opplevelser fra å sove ute og leve på siden av samfunnet. Vi kan tolke hans arbeid som et $\varnothing n s k e$ om å skape fornemmelser av et alternativt «hjem»:

Vi har grundlæggende trang til at omdanne of interagere i vores omgivlser, så vi føler os hjemme (Mønster, 2009, s.358).

Perrimans grunnleggende trang til å belyse gaten som et hjem gir seg uttrykk i fotoessay, blogg og lydinstallasjoner som ledd i kunstnerisk forskning. Dette arbeidet definerer han som «site-spesific artistic interventions». ${ }^{21}$ Prosjektet forankring til «sted» er vesentlig, for felles for alle disse stedene:

/.../ er endividere, at de ikke blot er. Steder bliver til derimod til i kraft at menneskets evne til at se stederne og gennem dets interaktion med dem (Mønster, 2009, s.359).

\footnotetext{
${ }^{20} \mathrm{http}: / /$ bekkiperriman.co.uk/?page_id=111

${ }^{21}$ http://bekkiperriman.co.uk/?page_id=111
} 
Man kan forstå hans ståsted som sosial-økonomisk marginal, noe som skaper en form for sosial funksjonsnedsettelse i møtet med majoritetssamfunnet.

Inspired by the artist»s own experience of life on the streets, the project uses a direct and unsentimental approach to investigating the personal, social and political dimensions of homelessness and offers an opportunity to listen to society»s most silenced voices. ${ }^{22}$

Nettopp hans innenfra-perspektiv gjør The Doorways Project potent, vitalt og åpent for et stort spekter av fornemmelser hos publikum. Perriman har politiske målsetninger med prosjektet og ønsker således å endre og omformulere det samfunnet han lever i, slik at tilliten, medlidenheten og oppriktigheten gis bredere spillerom for alle, ikke bare for de privilegerte med markante røster i offentligheten. Han står frem med et oppriktig ønske om å skape tillit til hjemløses røster, for å få folk til å medlidende respektere røstens kraft, fremfor å degradere den og plassere denne røsten utenfor fellesskapet. Han vil motvirke det Bauman kaller «et savnet felleskap» som kjennetegner vår tid (Bauman, 2000).

Det andre prosjektet jeg ønsker å trekke frem fra UNLIMITED-festivalen i London, er Sue Austins Flying Free. Kunstneren Sue Austin omtaler rullestolen som et «rom» for utforskning, hun bruker begrepet «power-chair» $\mathrm{i}$ betydningen «stol» som gir «makt». Austin benytter videokunst, koreografi og bevegelse for å uttrykke menneskets naturgitte sanselighet i møtet med naturen. Vi kan fenomenologisk betrakte kroppen og elementene som naturgitte fenomen vi lever i og gjennom (Merleau-Ponty, 1968). Elementet vann er Austins scenografiske ramme der hun bruker rullestolen som en transformasjonsarena.

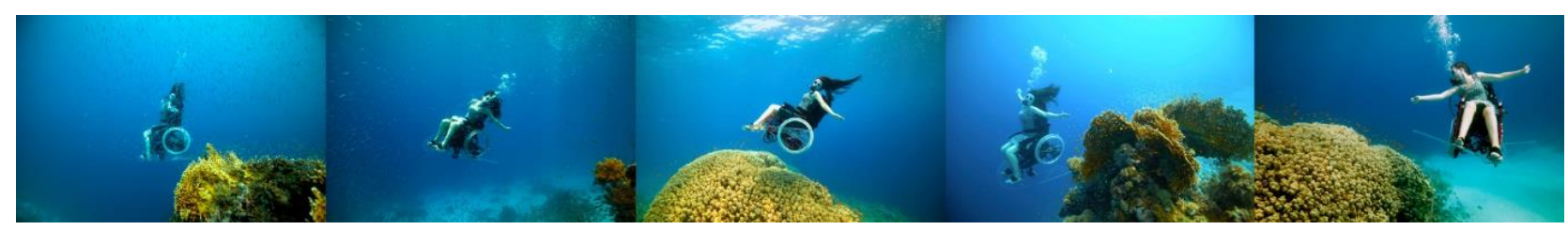

Sue Austin omtaler rullestolen som: "A vehicle for transformation, into a new level of conciseness". ${ }^{23}$ Fornemmelsen Austin beskriver, oppstår når hun kunstdidaktisk omformer hjelpemidler til estetiske objekt og bruker dem som utforskningsmedium fremfor å betrakte dem som skambelagte objekter med negative konnotasjoner:

/.../ facilitating new ways of seeing, being and knowing. In her art, she aims to convey the spirit of wonder she feels wheeling through the world. Includes thrilling footage of an underwater wheelchair that lets her explore ocean beds, drifting through schools of fish, floating free in 360 degrees. $^{24}$

Betraktninger av undervannsperformancen Flying Free bringer oss inn på undringene over hvem som fornemmer når kunstdidaktikken møter marginale røster. Nettopp fordi både Sue Austin og Bekki Perriman skaper kunst basert på egne livsytringer (Løgstrup, 1978), gir de kunstdidaktikken nytt perspektiv når funksjonsnedsettelsen iscenesettes filosofisk, estetisk og politisk. Austins og Perrimans kroppslige og emosjonelle fornemmelser gir tanker og følelser rom gjennom undervannsdansen og lydinstallasjonen. Publikum settes så i neste runde i bevegelse, for det er gjennom tilliten, medlidenheten og oppriktigheten at vi finner «rom», rom til nye tanker om menneskets plass i samfunnskroppen. Vi avslutter nå vandringen vender oss mot siste stopp på denne vandringen i selve rommeligheten.

\footnotetext{
${ }^{22} \mathrm{http} / / / \mathrm{www}$. southbankcentre.co.uk/whatson/bekki-perriman-the-doorways-project-1000578

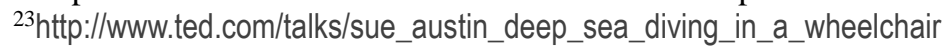

${ }^{24} \mathrm{http}$ ://www.wearefreewheeling.org.uk/sue-austin-home
} 


\section{Rommeligheten}

Rommelig betyr vidtrekkende, gedigen, ruvende, mektig, omfangsrik og omfattende. ${ }^{25}$ Begrepet sprenger altså grensene for et lukket rom. Dermed er rommeligheten åpnende, velkommen og grensesprengende. Når mennesker når fram til rommeligheten, gir det ro. For rommelighet handler om å vende hjem hevder Pahuus (2015, s.133). Mennesket lengter alltid «hjem» til tilhørigheten og dermed menneskets væren på stedet. Byen fremstår som et trygt sted for oss når den «/.../ samler meninger som går ut over den lokale situasjon, dog uten å miste sine trygge røtter i denne» (Norberg-Schulz, 1978, s.68). Hjemmet er de trygge røttene vi trenger for med tillit i eget liv å kunne skue ut på utfordringene. Først når vi kan gi rom for andre, skape dialogrom mellom det kjente og ukjente, når vi som mennesker fram til rommeligheten i livet.

Hva innebærer så «rommelighet» for kunstdidaktikeren, kunstneren og publikum? Vi skal vende oss til UNLIMITED-prosjektet Take me to bed av kunstnerne Luke Pell and Jo Verrens for å undre oss over det sammen.

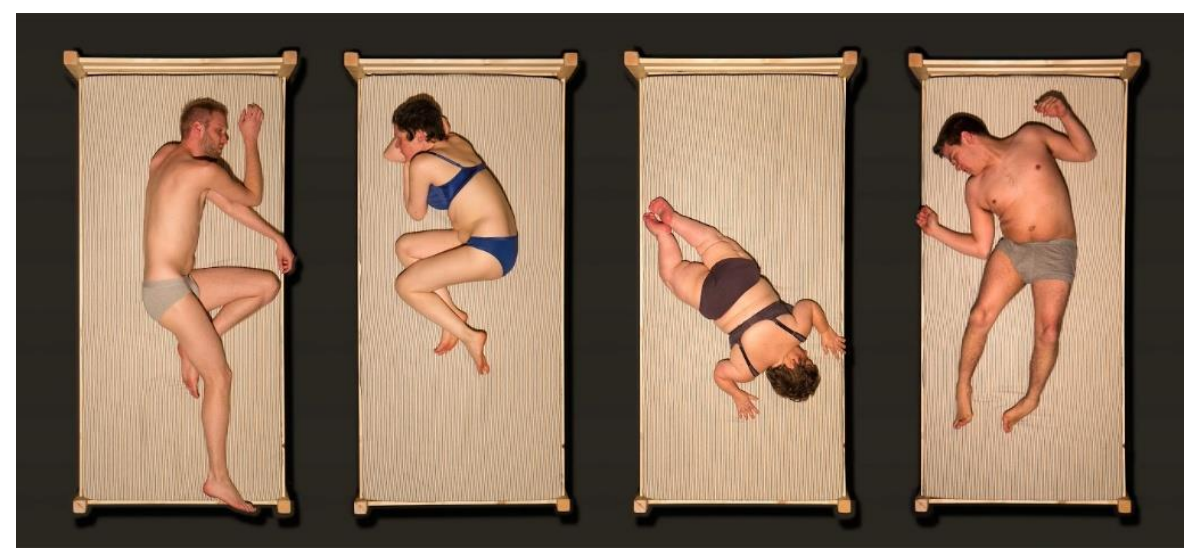

Installasjonen Take med to bed handler om å komme nær seg selv, være nysgjerrig, kjempe og overgi seg, ifølge Pell \& Verrens. Kunstnerne iscenesetter funksjonshemmede dansere med det de kaller «particular bodies» og leker med intimitetens grense foran publikums øyne. Prosjektet er en utforskning av «/.../ our responses to «othered» bodies and their dances». Verket består av flere filmer av sengeliggende, sovende dansere som bare er ikledt undertøy (https://vimeo.com/95332775). «Take me to bed explores the (dis)comfort of audiences around bodies that are different". ${ }^{26}$ Installasjonen utforsker derfor nettopp rommeligheten i betrakteren. Sengen er nest etter baderommet det rommet der intimitetens grense er nådd for de aller fleste. Dermed er vi som mest nakne når vi skuer ut over sovende kropper, fordi vi gjenkjenner på egen kropp opplevelsen av å være sovende tilstede i rommet. Man er ultrasårbar når man ikke enser andres blikk fordi man har glidd inn i søvnens univers. For betrakteren av filmen er nok det mest ubekvenne ens eget blikk på de sovende men også oppdagelsen av den annerledes kroppen. Kroppen fremtrer nemlig for betrakteren som hypersynlig i filmen der den ligger på canvasunderlaget. Ifølge Petra Kuppers (2006) dekker nettopp begrepet hyper visible fenomenet som oppstår når vi ser på ser på funksjonshemmedes kropper og betrakter dem, skammer oss over dommen vi feller og vender blikket ned for deretter å se igjen. Dette kan man kalle «the disability act» (Kuppers, 2006), når kroppene på filmen spiller i en iscenesettelse av betrakterens blikk. Filmene byr på mangfoldet i menneskeheten. Vi ser lange, korte, brede og tynne kopper som tolkes i vårt blikk. Vi

\footnotetext{
${ }^{25} \mathrm{http}: / /$ www.ordetbetyr.com/synonym/rommelig

${ }^{26} \mathrm{http} / / /$ unlimited.southbankcentre.co.uk/assets/uploads/files/UNLIMITED\%202014\%20-\%20Brochure.pdf
} 
former tanken om det vi anser som vanlig og uvanlig. Men subjektene på bildene er jo alle stille sovende og slik sett naturlige og ikke unaturlige. Det naturlige mangfold vokser frem i den kunstdidaktiske prosessen kunstnerne Pell \& Verrens byr betrakteren med på. Prosessen tar tid, og vi kjenner at vi i filmbetraktningen beveger oss fra fornemmelser til fordommer og undringer. Til slutt banker vi kanskje på tålmodighetens dør? Vi står og ser, tenker og ser. Slipper vi innenfor tålmodighetens dør, kan vi nå inn til «rommeligheten». Døren er likevel ikke umiddelbart åpen. For å komme inn må vi banke på, altså vise vilje og ta standpunkt. Vi må våge å si til oss selv at: Det kunne vært meg - vi er Like og uLike på samme tid.

\section{Oppsummerende undringer}

Det er først når landskapet oppleves som kjent og husene står støtt, at vi som kunstdidaktikere, kunstnere eller betraktere kan kjenne rommeligheten i oss. Vi har i denne artikkelen studert et anvendt dramahelseprosjekt, et samtidsteaterprosjekt, en foto- og lydinstallasjon, en koreografert undervannsdans og en film av sovende kropper med den hensikt å åpne et undringsfelleskap som kan utvide vår forståelse for marginalitet og kunstdidaktikk. Vi har sett at husene i landskapet rundt oss har ulike objektivt gitte rom, aktivitetsrom og fornemmede rom der kunstdidaktikken kan omdannes nettopp til et mulighetenes rom når man som kunstdidaktiker også makter å tre inn i rommeligheten. Slik sett kan stedsfilosofien berike kunstdidaktikken, siden alt kunstdidaktisk arbeid er forankret på et sted der man lytter til en røst. Denne røsten kan være marginal eller høylytt, kjent eller ukjent. Kunstdidaktikken kan gi alle røster mulighet for brofeste i livet når kunstverk og kunstfaglige prosesser vokser fra et sted og ut mot mennesker som er til-stede-værende i livet og som ønsker å være rommelige og nå fram til rommeligheten. Tilstedeværelse er som kjent en kjerneverdi i all menneskelig væren, også i estetikkens univers. John Dewey (1934) peker på at til-stede-værelse, bevisst og henvendt, konsentrert og fokusert, er det som kan omdanne en hverdagserfaring til en genuin estetisk erfaring. Når omdanningen skjer, er det nemlig på grunn av et møte mellom mennesker eller mellom mennesket og verket. Det er i denne konsentrerte relasjon at vi kan kjenne vår egen væren intens og erfare estetisk gjennom alle sansene våre. Uansett funksjonsnedsettelse eller marginalisering er alle mennesker i stand til å erfare estetisk gjennom kunst eller natur, siden menneskets emosjonelle, kroppslige og kognitive ressurser i erfaringsprosessen anvendes på individets premisser for levd liv (Gürgens, 2004).

Kunsteksemplene vi nå har studert, representerer ulike kunstarter, forskjellige sjangre og et spekter av kunstsyn. Likevel har de det til felles at de kunstdidaktisk åpner muligheten for at mennesker med marginale røster kan komme til syne i offentligheten. Prosjektene kommuniserer til betrakteren og aktøren et menneskesyn som er likeverdig og en forståelse av at kunsten er vevd inn i samfunnskroppen som en erkjennende puls som lever i oss og gjennom vår medmenneskelighet. Løgstrup (1978) har vist oss at det er gjennom tilliten, medlidenheten og oppriktigheten at vi finner rom, de er suverene livsytringer og gitt ved livet selv (Martinsen, 2015, s.21). De gir tanker og følelser rom, og nettopp her mener jeg at vi finner utfordringene for kunstdidaktikken. Å skape en kunstdidaktikk som er åpen for alle mennesker krever at vi gjennomgående befester et likeverdsfokus i kunsten som i livet. Dette er utfordrende for kunsten, ikke for kunstens grunnleggende premiss om at alle mennesker er skapende, men for kunstens elitisme, hierarki, makt og institusjonalisering. 


\title{
Forfatteromtale:
}

Rikke Gürgens Gjærum, professor ved HIOA, med delstilling ved Universitet i Tromsø. Dr.at. v/NTNU i 2004, hovedfag i teatervitenskap v/UIO i 1998, allmennlærer og dramapedagog. Arbeider med anvendt teaterforskning, disability art, reminisensteater, estetikkfilosofi og kunstbaserte forskningsmetoder, men også med teaterkritikk, barne- og ungdomsteater og ulike anvendte antistigmatiserende teaterprosjekter $\mathrm{i}$ «Usedvanlig teater».

\begin{abstract}
The article explores Art Didactics as a room for possibilities for marginal voices. Through place philosophy the term "room" represents the metaphorical fulcrum in the article. The purpose is to open up an amazement community where we together walk the philosophical path from room to room in order to expand our understanding of both Marginality and Arts Didactics. The article contribute with a concept- and theory development concerning Art for, of and with people with marginal voices, seen through contemporary art examples from Disability Art represented by DE UTVALGTE and UNLIMITED 2014.
\end{abstract}

\section{Litteraturliste:}

Aristoteles. (1999) Den nikomakiske etikk, Oslo: Bokklubben dagens bok.

Aure, Venke (2013). Didaktikk - i spennet mellom klassisk formidling og performativ praksis. InFormation - Nordic Journal of Art and Research. Vol. 2. doi: 10.7577/if.v2i1.611, http://hdl.handle.net/10642/1931

Bauman, Z. (20000). Savnet felleskap, Oslo: Cappelen Damm.

Becker, H.S. (1963) Outsiders: Studies in the sociology of deviance, New York: The Free Press.

Bourriaud, (2007) Relasjonell estetikk, Oslo: Pax forlag.

Brodzinski, E. (2010) Theatre in Health and Care, London: Palgrave.

Brook, P. (1995). The Empty Space: A Book About the Theatre: Deadly, Holy, Rough, Immediate, New York: Tutchstone.

Clancy, A., Svensson, T. (2007). «Faced» with responsibility: Levinasian ethics and the

challenges of responsibility in Norwegian public health nursing, Nursing Philosophy, 8, s. 158-166.

Conroy, C. (2009).Disability: Creative tensions between drama, theatre and disability arts. In: Research in Drama Education, 02.2009, s. 1-14.

Dewey, J. (1934). Art as experience, New Yorg: Perigee.

Freire, P. (1996). Pedagogy of the Oppressed, London: Penguin Education.

Kuppers, Petra (2006). Vibrant Agencies: Dance, Disability Embodiment and Phenomenology. In Ramsay

Gadamer, H.G. (2012) Sannhet og metode, Oslo: Pax forlag.

Gürgens, R. (2004) En usedvanlig estetikk, Trondheim: NTNU trykk.

Heidegger, M. (1962). The being of time, Oxford: Blackwell Publiers Ltd.

Foucault, M. (1972) The Archaeology of knowledge \& The Discourse of language, New York: Tavistock Publications Limited.

Fugelli, P. (2013) Journalen, Oslo: Universitetsforlaget.

Hansen, F.T. (2008) At stå I det åpne, dannelse gennom filosofisk undren og narvar, København: Hans Reitzels forlag.

Løgstrup. K.E. (1978) Skabelse og tilintetgфrelse, København: Gyldendal forlag.

Pahuus, M. (2015) Det levende rom, med sideblikk på syepleie, I Kjær, T.A., Martinsen, K. (2015) Utenfor tellekantene: essays om rom og rommelighet, Bergen: Fagbokforlaget.

Martinsen, K. (2015) Er sykeværelse med interiør og ting hjelpende? Om stedstap og sted i helsevesenet, i Kjær, T.A., Martinsen, K. (2015) Utenfor tellekantene: essays om rom og rommelighet, Bergen: Fagbokforlaget.

Merleau-Ponty, M. (2004). The world of Perception, New York: Routledge. 
Merleau-Ponty, M. (1968) The Visible and the Invisible. Northwestern: University Press.

Mønster, L. (2009). At finde sted: En introduction til stedsbegrebet og det litterære potentiale, Edda, vol. 109, s. 357-373.

Taylor, P. (2003). Applied Theatre: Creating transformtative encounters in the community. Portsmouth: Heinemann

Trønnes-Christensen, T. (2014). Jeg rekker opp hånden for deg, Når storebror har Downs syndrom, Oslo: Cappelen Damm.

Van Manen, M. (1990). Researching Lived Experience. Albany: State University of New York Press.

\section{Nettkilder:}

http://www.abcnyheter.no/livet/2013/08/24/180480/varsomme-sykehusklovner-muntrer-opp-desyke?nomobile $=1$

http://bekkiperriman.co.uk/?page_id=111

http://www.deutvalgte.no/portfolio_page/de-utvalgte/

http://dictionary.reference.com/browse/room

http://www.disabilityartsonline.org

http://www.roaring-girl.com/work/resistance/

http://www.southbankcentre.co.uk/whatson/bekki-perriman-the-doorways-project-1000578

http://www.ted.com/talks/sue_austin_deep_sea_diving_in_a_wheelchair

http://UNLIMITED.southbankcentre.co.uk/

http://unlimited.southbankcentre.co.uk/assets/uploads/files/UNLIMITED\%202014\%20-

$\% 20$ Brochure.pdf

https://vimeo.com/95332775

http://www.wearefreewheeling.org.uk/sue-austin-home 